Tropical Journal of Pharmaceutical Research May 2020; 19 (5): 1009-1013

ISSN: $1596-5996$ (print); 1596-9827 (electronic)

(C) Pharmacotherapy Group, Faculty of Pharmacy, University of Benin, Benin City, 300001 Nigeria

\title{
Paclitaxel liposomes exert radio-sensitization effect on breast cancer cell line SK-BR-3 by regulating expressions of apoptotic proteins
}

\author{
Guoling Yin*, Xiaoping Li, Xiaofei Chang \\ Department of Radiation Oncology, Helping Hospital Changzhi Medical College, Changzhi, PR China
}

*For correspondence: Email: k0qwqg@163.com

Sent for review: 3 February 2020

Revised accepted: 26 April 2020

\begin{abstract}
Purpose: To study the radio-sanitization effect of paclitaxel liposomes on breast cancer cells, SK-BR-3. Methods: Breast cancer cell line SK-BR-3 was cultured and made into a cell suspension. Four groups of cells were used: control and radiotherapy groups, paclitaxel group, and paclitaxel liposome + radiotherapy group (combination group). The growth inhibitory effects of the different treatments on SKBR-3 cells were determined with CCK-8 method. Apoptosis in each group was evaluated with flow cytometry, while Western blotting was employed to assay Bcl-2, Caspase-3 and Bax protein levels.

Results: There were marked inhibitory effect on growth of SK-BR-3 cells in drug, radiotherapy and combination groups, relative to control, while apoptosis was greater in combination group than in drug and radiotherapy groups $(p<0.05)$. The Bcl-2 protein level was higher in radiotherapy, drug and combination groups than in control group, while Caspase-3 and Bax proteins were markedly higher than control values $(p<0.05)$.

Conclusion: Paclitaxel liposomes exert radio-sensitization effect on SK-BR-3 by regulating the levels of apoptotic proteins. This provides a basis for research and development of new drugs.
\end{abstract}

Keywords: Paclitaxel liposomes, Apoptotic proteins, Breast cancer, SK-BR-3, Radiotherapy, Sensitization, Bcl-2, Caspase-3, Bax

This is an Open Access article that uses a fund-ing model which does not charge readers or their institutions for access and distributed under the terms of the Creative Commons Attribution License (http://creativecommons.org/licenses/by/4.0) and the Budapest Open Access Initiative (http://www.budapestopenaccessinitiative.org/read), which permit unrestricted use, distribution, and reproduction in any medium, provided the original work is properly credited.

Tropical Journal of Pharmaceutical Research is indexed by Science Citation Index (SciSearch), Scopus, International Pharmaceutical Abstract, Chemical Abstracts, Embase, Index Copernicus, EBSCO, African Index Medicus, JournalSeek, Journal Citation Reports/Science Edition, Directory of Open Access Journals (DOAJ), African Journal Online, Bioline International, Open-J-Gate and Pharmacy Abstracts

\section{INTRODUCTION}

Breast carcinoma is a frequently-occurring malignancy in women, accounting for more than $22 \%$ of all female malignancies, and is a major factor involved in death of women. Currently, more than 1.5 million people worldwide develop breast cancer each year, and more than 400,000 people die from it [1]. The incidence of breast cancer is increasing year by year, with severe effects on people's life and health. Radiation therapy, referred to as radiotherapy, is one of the conventional treatment strategies for tumors in traditional Chinese medicine.

However, patients may have recurrence or adverse reactions during the course of radiation therapy [2]. During the radiotherapy treatment, various factors such as proportion of hypoxic cells, sublethal or potentially lethal repair, and 
cell re-proliferation generate radio-resistance in tumor cells, resulting in adverse and significant impact on the efficacy of radiotherapy [3]. Therefore, it is crucial to evolve safe and effective ways to enhance radiotherapy effect.

Paclitaxel is a yew extract with cytotoxic effects on many types of tumor cells. Paclitaxel liposomes are derived from paclitaxel, cholesterol and phosphatidic acid [4]. As drug delivery carriers, liposomes have the advantages of hydrophilicity, lipophilicity, targeting and low side effects. Karagiannis et al [5] reported that paclitaxel liposomes exert cytotoxic effects, and markedly reduce the adverse reactions of drugs.

The present research was carried out to investigate radio-sensitizing effect of paclitaxel liposomes on SK-BR-3 cells, and the mechanism involved.

\section{EXPERIMENTAL}

\section{Cell line}

The SK-BR-3 cells were product of Shanghai Supan Biotechnology Co. Ltd.

\section{Main reagents and instruments}

Dulbecco modified eagle medium (DMEM) was bought from Thermo Fisher Scientific (China) Co., Ltd. Biological microscope was product of Jingtong Life Science Instrument Co. Ltd, model VMB2200A). Cryogenic high-speed centrifuge was product of Huawei Kechuang (Wuhan) Technology Co. Ltd. (model SIGMA3-18K). Flow cytometer was bought from Beckman Coulter Trading (China) Co. Ltd. (model: CytoFLEX). Cell counter was obtained from Shanghai Naai Precision Instrument Co. Ltd. (model NAI3536). Refrigerator $\left(-80^{\circ} \mathrm{C}\right)$ was purchased form Nanjing Bay Deng Medical Co. Ltd, model MDF-C8V. Fetal Bovine Serum was product of Punose Life Technology Co. Ltd.

Trypsin was supplied by Shanghai Yaxin Biotechnology Co. Ltd. Penicillin-streptomycin (Pen-Strep) Double Antibody was a product of Juneng Century Information Technology (Suzhou) Co. Ltd. Paclitaxel was purchased from Fresenius Kabi USA, LLC; specification: 100 $\mathrm{mg} /$ bottle). Rabbit anti-human Bcl-2 monoclonal antibody was product of Beijing Taize Ruida Technology Co. Ltd. Rabbit anti-human Caspase-3 monoclonal antibody was bought from Shanghai Ye Sheng Biotechnology Co. Ltd. Rabbit anti-human Bax polyclonal antibodies were obtained from Shanghai Xuan Ling Biological Technology Co. Ltd.
Determination of apoptosis and growth inhibition

Breast cancer cell line SK-BR-3 was cultured at $37^{\circ} \mathrm{C}$ in DMEM containing $15 \%$ FBS and PenStrep double antibody $(10 \mathrm{~g} / \mathrm{L})$ in an environment with $5 \%$ carbon dioxide $\left(\mathrm{CO}_{2}\right)$. At about $85 \%$ confluence, the cells were sub-cultured. The experiments were performed using cells at logarithmic phase. When the cell density grew to about $75 \%$, the original medium was discarded, and the cells were rinsed in phosphate buffer, made into a cell suspension, and stored in liquid nitrogen.

The CCK-8 method was used to measure the growth inhibition in different treatment groups (control group, radiotherapy group, paclitaxel group and combination group). The cells were prepared into a cell suspension and plated at a concentration of 4000 cells/well. Paclitaxel liposomes $(20 \mathrm{mmol} / \mathrm{L})$ were added to the drug group and combination group. Thereafter, $10 \mu \mathrm{L}$ of CCK-8 solution was put in each well, followed by incubation for $2 \mathrm{~h}$ in the dark, after which the absorbance of each well was read at $550 \mathrm{~nm}$.

Apoptosis was determined using flow cytometry. The treated SK-BR-3 cells were cultured for $24 \mathrm{~h}$, and centrifuged at $3000 \mathrm{rpm}$. The supernatant was discarded, and apoptosis of the SK-BR-3 cells was measured flow cytometrically. The expressions of apoptosis-related proteins were assayed using Western blotting.

\section{Statistical analysis}

Measured data are shown as mean \pm SD, and were analyzed with single factor ANOVA and LSD (Least Significant Difference) $t$-test. Count data comparison was performed with $X^{2}$ test. All statistical analyses were done with SPSS 19.0. Statistical significance was assumed at $p<0.05$.

\section{RESULTS}

\section{Growth inhibitory effects of drug, radiotherapy and combination}

As shown in Table 1, the drug, radiotherapy and combination groups produced significant growth inhibitory effects, when compared with the control group. Inhibitory effect was markedly higher in combination group than in drug group and radiotherapy group. However, growth inhibitory effects in the drug and radiotherapytreated cells were comparable $(p>0.05)$. 
Table 1: Growth inhibitory effects of different treatments on SK-BR-3 cells

\begin{tabular}{lc}
\hline Group & Growth inhibition (\%) \\
\hline Control & 0 \\
Drug & $43.26 \pm 14.47^{\mathrm{a}}$ \\
Radiotherapy & $42.54 \pm 16.29^{\mathrm{a}}$ \\
Combination & $71.52 \pm 19.66^{\mathrm{ab}}$ \\
$F$ & 10.51 \\
$P$-value & 0.001 \\
\hline
\end{tabular}

Data are mean \pm SD. ${ }^{a} P<0.05$, vs control; ${ }^{b} p<0.05$, vs drug and radiotherapy groups.

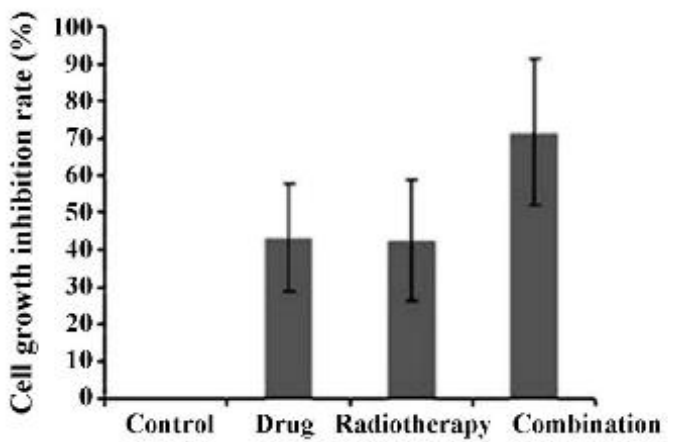

Figure 1: Growth inhibitory effect of different treatments on SK-BR-3 cells

\section{Apoptosis}

Apoptosis was markedly increased in drug, radiotherapy and combination groups, relative to control. Moreover, it was markedly higher in combination group than in drug group and radiotherapy group $(p<0.05)$. However, apoptosis was comparable between the drug group and radiotherapy group. These findings are presented in Table 2 and Figure 2.

Table 2: Apoptosis amongst the groups

\begin{tabular}{lc}
\hline Group & Apoptosis (\%) \\
\hline Control & $0.13 \pm 0.03$ \\
Drug & $2.63 \pm 0.14^{\mathrm{a}}$ \\
Radiotherapy & $2.75 \pm 0.19^{\mathrm{a}}$ \\
Combination & $17.33 \pm 3.94^{\mathrm{ab}}$ \\
$F$ & 126.25 \\
$P$ & $<0.001$ \\
\hline \multicolumn{2}{l}{ Data are mean \pm SD. ${ }^{a} P<0.05$, vs control; ${ }^{b} p<0.05}$, \\
vs drug and radiotherapy groups.
\end{tabular}

\section{Apoptotic protein expressions among the groups}

In radiotherapy, drug and combination groups, Bcl-2 protein concentrations were markedly reduced, relative to that in control, while Caspase- 3 and Bax proteins were raised, relative to control levels $(p<0.05)$. The $\mathrm{Bcl}-2$ protein in combination group was significantly lower than those in radiotherapy and drug groups.
Moreover, Caspase-3 and Bax were upregulated relative to the corresponding expressions in the radiotherapy group and the drug group $(p<0.05$; Figure 3 and Table 3 ).

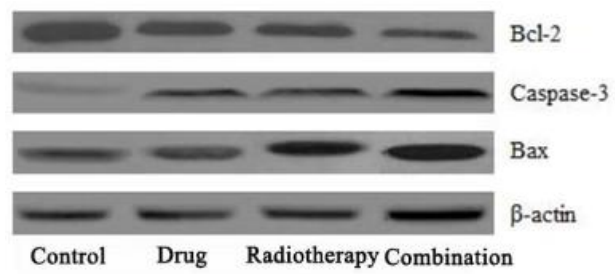

Figure 3: Expressions of $\mathrm{Bcl}-2$, Caspase-3 and Bax levels among the groups

Table 3: Comparison of Bcl-2, Caspase-3 and Bax protein levels among the groups

\begin{tabular}{llllllll}
\hline Group & Bcl-2 & \multicolumn{2}{l}{$\begin{array}{l}\text { Caspase- } \\
\text { 3 }\end{array}$} & \multicolumn{2}{l}{ Bax } & \\
\hline Control & 1.01 & \pm & 1.01 & \pm & 1.01 & \pm \\
& 0.01 & & 0.01 & & 0.01 & \\
Drug & 0.76 & \pm 1.25 & \pm & 1.18 & \pm \\
& $0.02^{\mathrm{a}}$ & & $0.04^{\mathrm{a}}$ & & $0.02^{\mathrm{a}}$ & \\
Radiotherapy & 0.74 & \pm .21 & \pm & 1.19 & \pm \\
& $0.03^{\mathrm{a}}$ & & $0.07^{\mathrm{a}}$ & & $0.03^{\mathrm{a}}$ & \\
Combination & 0.37 & \pm & 1.59 & \pm & 1.42 & \pm \\
$F$ & $0.01^{\mathrm{ab}}$ & $0.03^{\mathrm{ab}}$ & & $0.06^{\mathrm{ab}}$ & \\
$P$ & 148.38 & 247.32 & & \multicolumn{2}{c}{181.33} & \\
& $<0.001$ & $<0.001$ & & $<0.001$ & \\
\hline
\end{tabular}

Data are mean \pm SD. ${ }^{a} P<0.05$, vs control; ${ }^{b} p<0.05$, vs drug and radiotherapy groups

\section{DISCUSSION}

Malignant tumors are serious threats to human life and health. Breast cancer is the most prevalent malignancy in females. Due to increases in the incidence of breast cancer, the screening, diagnosis and treatment technologies for breast cancer are regularly improving, resulting in early diagnosis [6]. In order to improve the cosmetics and quality of life of postoperative patients, early breast-conserving treatment has been promoted. Radiotherapy kills tumor cells through ionizing radiation. At present, radiotherapy is indispensable in the treatment of breast cancer by improving the restriction of local tumors and long-term survival of patients [7]. However, due to their increased resistance to radiation, the recurrence of breast malignancy is also on the increase. Therefore, it is important to develop more effective radiation-sensitizing drugs for breast cancer.

Paclitaxel, a drug often used clinically in ovarian cancer and breast cancer, interrupts cell growth and promotes cell apoptosis by interfering with tubulin of cancer cells [8]. However, paclitaxel is hardly soluble in water. Moreover, the drug 
causes severe allergic reactions in patients. Liposomes are drug carriers composed of lipids and cholesterol. They regulate the fluidity and stability of membrane bilayers, and they reduce the side effects of drugs through targeted drug delivery $[9,10]$. In this research, the radiosensitizing influence of paclitaxel liposomes on SK-BR-3 cells, and the associated mechanism, were studied.

Cancer is associated with unregulated growth and proliferation of mutated cells (without differentiation), which eventually disrupt normal physiological functions, leading to death of the patients [11]. In this study, CCK-8 method was used to test growth suppression in each group, and it was found that there was significant inhibitory effects on the growth of SK-BR-3 cells in the drug group, radiotherapy group and combination group. The growth inhibitory effect of the combination group was markedly higher than that of the drug group and radiotherapy group, while the drug group and radiotherapy group had no significant difference in the growth inhibitory effect on SK-BR-3 cells. This shows that paclitaxel liposomes significantly improved the radio-sensitivity of SK-BR-3 cells.

Apoptosis is a vital biological process. It is crucial to maintain a dynamic balance between apoptosis and cell proliferation, for proper physiological function. Through apoptosis, cells that have reached the end of their lives are selectively cleared and digested. Thus, apoptosis is of significance in maintenance of normal morphology of tissues and organs [12]. It entails activation, expression and regulation of a series of genes. It is known that $\mathrm{Bcl}-2$ is a tumor suppressor gene which, along with Bax, belongs to the Bcl-2 protein family. Caspase- 3 is a cysteine protease which specifically cleaves after the aspartic acid residue of the target protein [13].

Studies have found that Caspase-3 plays an irreplaceable role in apoptosis [14]. As a cancerpromoting gene, Bax is normally distributed in the cytoplasm. When cells are stimulated, Bax induces the release of cytochrome $\mathrm{C}$, thereby promoting apoptosis [15]. The results obtained in the present research suggest that paclitaxel exerts radio-sensitizing effect on breast cancer SK-BR-3 cells through a mechanism closely related to regulation of apoptotic protein expressions.

\section{CONCLUSION}

This study demonstrates that paclitaxel liposomes may be beneficial in the radio- sensitization of breast cancer cells SK-BR-3 via regulation of the expressions of $\mathrm{Bcl}-2$, Caspase3 , and Bax. These findings provide a useful basis for research and development of new drugs.

\section{DECLARATIONS}

\section{Conflict of interest}

No conflict of interest is associated with this work.

\section{Contribution of authors}

We declare that this work was done by the author(s) named in this article and all liabilities pertaining to claims relating to the content of this article will be borne by the authors. All authors read and approved the manuscript for publication. GuoLing Yin conceived and designed the study, GuoLing Yin, Xiaoping Li, Xiaofei Chang collected and analysed the data, while GuoLing Yin wrote the manuscript.

\section{Open Access}

This is an Open Access article that uses a funding model which does not charge readers or their institutions for access and distributed under the terms of the Creative Commons Attribution License (http://creativecommons.org/licenses/by/ 4.0) and the Budapest Open Access Initiative (http://www.budapestopenaccessinitiative.org/rea d), which permit unrestricted use, distribution, and reproduction in any medium, provided the original work is properly credited.

\section{REFERENCES}

1. Duan H, Johnston SA, Shen LH. Abstract 660: Presymptomatic detection and early treatment of mammary cancer with anti-PD-L1 in a mouse mode. Cancer Res 2017; 77(13): 660-660.

2. Kowalski ES, Feigenberg SJ, Cohen J, Fellows Z, Vadnais $P$, Rice S, Mishra MV, Molitoris JK, Nichols EM, Snider JW 3rd. Optimal Target Delineation and Treatment Techniques in the Era of Conformal Photon and Proton Breast and Regional Nodal Irradiation: Breast Nodal Optimal Target Delineation. Pract Radiat Oncol 2019; 8500(19): 30359.

3. Darabpour S, Kheirkhah M, Ghasemi E. Effects of Swedish Massage on the Improvement of Mood Disorders in Women with Breast Cancer undergoing Radiotherapy. Iran Red Crescent Med J 2016; 18: 25461.

4. Kanlikilicer $P$, Bayraktar R, Denizli $M$, Rashed MH, Ivan C, Aslan B, Mitra R, Karagoz K, Bayraktar E, Zhang X, et al. Exosomal miRNA confers chemo resistance via

Trop J Pharm Res, May 2020; 19(5): 1012 
targeting Cav1/p-gp/M2-type macrophage axis in ovarian cancer. EBioMedicine 2018; 38: 100-112.

5. Karagiannis GS, Harney AH, Wang $Y$, Pastoriza JM, Pignatelli J, Anampa J, Sparano JA, Jones JG, Entenberg D, Condeelis JS, et al. Abstract 244: Paclitaxel increases the assembly and function of the tumor microenvironment of metastasis in breast cancer. Cancer Res 2016; 76(14): 244-244.

6. Wang M, Feng HL, Liu YQ, Liu H, Jiang YX, Zhu QL, Dai Q, Li JC. Angiogenesis Research in Mouse Mammary Cancer Based on Contrast-enhanced Ultrasonography. Acad Radiol 2018; 25(7): 889-897.

7. Zhang A, Li S, Zhang Y, Jiang F, Jin X, Ma J. Nocturnal enuresis in obese children: a nation-wide epidemiological study from China. Sci Rep 2019; 9(1): 8414.

8. Moutal A, Wang Y, Yang X, Ji Y, Luo S, Dorame A, Bellampalli SS, Chew LA, Cai S, Dustrude ET, et al. Dissecting the role of the CRMP2-Neurofibromin complex on pain behaviors. Pain 2017; 158(11): 22032221.

9. Kokkali S, Tripodaki ES, Drizou M, Stefanou D, Magou E, Zylis D, Kapiris M, Nasi D, Georganta C, Ardavanis A. Biweekly Gemcitabine/Nab-Paclitaxel as First-line Treatment for Advanced Pancreatic Cancer. Vivo 2018; 32(3): 653-657.

10. Karagiannis GS, Pastoriza JM, Wang Y, Harney AS, Entenberg D, Pignatelli J, Sharma VP, Xue EA, Cheng
E, D'Alfonso TM, et al. Neoadjuvant chemotherapy induces breast cancer metastasis through a TMEMmediated mechanism. Sci Transl Med 2017; 9(397): 26.

11. Chang $S$, Chen $B$, Wang $X, W u K$, Sun $Y$. Long noncoding RNA XIST regulates PTEN expression by sponging miR-181a and promotes hepatocellular carcinoma progression. BMC Cancer 2017; 17(1): 248.

12. Ma YV, Lam C, Dalmia S, Gao P, Young J, Middleton K, Liu C, Xu H, You L. Mechanical regulation of breast cancer migration and apoptosis via direct and indirect osteocyte signaling. J Cell Biochem 2018; 119(7): 56655675.

13. Soto-Mercado V, Mendivil-Perez M, Uruena-Pinzon C, Fiorentino S, Velez-Pardo C, Jimenez-Del-Rio M. TPEN Exerts Antitumor Efficacy in Murine Mammary Adenocarcinoma Through an $\mathrm{H} 2 \mathrm{O} 2$ Signaling Mechanism Dependent on Caspase-3. Anticancer Agents Med Chem 2018; 18(11): 1617-1628.

14. Tu SH, Chiou YS, Kalyanam N, Ho CT, Chen LC, Pan $\mathrm{MH}$. Garcinol sensitizes breast cancer cells to Taxol through the suppression of caspase-3/iPLA2 and NF$K B / T$ wist1 signaling pathways in a mouse $4 T 1$ breast tumor model. Food Function 2017; 8(3): 1067-1079.

15. Lin B, Li D, Zhang L. Oxymatrine mediates Bax and Bcl-2 expression in human breast cancer MCF-7 cells. Pharmazie 2016; 71: 154-157. 